УДК 618.3-06:616.211-002-021.5] -036-08

DOI 10.11603/24116-4944.2017.1.7357

๑О. О. Корчинська ${ }^{1}$, К. П. Костур 1 , Н. В. Криванич ${ }^{1}$, М. М. Жила', С. Жултакова ${ }^{2}$, Г. Галдунова ${ }^{2}$

${ }^{1}$ ДВНЗ «Ужгородсъкий національний університет»

${ }^{2}$ Пряшівсъкий університет, Пряшів, Словацька Республіка

\title{
ОСОБЛИВОСТІ ПЕРЕБІГУ ТА ЛІКУВАННЯ АЛЕРГІЧНОГО РИНІТУ У ВАГІТНИХ
}

\begin{abstract}
Мета дослідження - розгляд особливостей клінічної картини, перебігу, терапії та профілактики сезонного алергічного риніту у вагітних жінок.

Матеріали та методи. Проведено огляд наукової літератури вітчизняних та зарубіжних авторів і видань у медичній бібліотеці Закарпатського обласного медичного інфрормаційно-аналітичного центру, оглянуто та проаналізовано джерела Інтернету.

Результати дослідження та їх обговорення. У статті розглянуто причини виникнення сезонного алергічного риніту у вагітних жінок, зазначено особливості його перебігу. Також показано вплив алергічного риніту на вагітність та плід, можливі ускладнення та наслідки даного захворювання. Наводяться особливості лікування алергічного риніту під час вагітності, розглядаються питання, що пов'язані з діагностикою та вибором лікарського засобу з урахуванням ступеня потенційної небезпеки препаратів для вагітної та майбутньої дитини. Проаналізувавши дані літературних джерел, авторами статті було виявлено, що від сезонного алергічного риніту страждає близько третини жінок репродуктивного віку, що підкреслює актуальність та наукову значимість даної теми. При вагітності симптоматика захворювання дещо змінюється, що утруднює його діагностику. В статті розглядається питання щодо терапії сезонного алергічного риніту у вагітних, особливістю якої $€$ те, що під час призначення медикаментозної терапії вагітним потрібно керуватися класифрікацією категорій ризику призначених препаратів (класисрікація FDA).

Висновки. Вагітні з алергічним ринітом потребують динамічного спостереження, адекватного лікування, контролю і оцінки ефективності призначеної терапії. Рекомендується проведення консиліуму у складі алерголога-імунолога, акушерагінеколога, а при необхідності й інших спеціалістів, для визначення тактики лікування та профрілактики загострень алергічних захворювань при вагітності. Незначна кількість праць та видань з даної теми свідчить про те, що дослідженням особливостей перебігу, діагностики, лікування та профрілактики алергічних захворювань під час вагітності майже не займаються ні акушери-гінекологи, ні алергологи. Оскільки ряд серйозних ускладнень даного захворювання може призвести до негативного впливу на організм як матері, так і дитини, тому питання розробки способів профрілактики та безпечної і ефективної терапії $\epsilon$ дуже важливим і може значно покращити якість життя. Ось чому для збереження здоров'я майбутньої матері і народження здорової дитини є необхідними знання про перебіг алергічного риніту у вагітних і причини його виникнення. Адже це дасть можливість правильно проводити підготовку, спостереження та лікування хворих на всіх строках вагітності.
\end{abstract}

Ключові слова: алергічні захворювання; алергічний риніт; вагітність; ускладнення.

ОСОБЕННОСТИ ТЕЧЕНИЯ И ЛЕЧЕНИЯ АЛЛЕРГИЧЕСКОГО РИНИТА У БЕРЕМЕННЫХ

Цель исследования - рассмотрение особенностей клинической картины, течения, терапии и профилактики сезонного аллергического ринита у беременных женщин.

Материалы и методы. Проведен обзор научной литературы отечественных и зарубежных авторов и изданий в медицинской библиотеке Закарпатского областного медицинского информационно-аналитического центра и проанализировано источники Интернета.

Результаты исследования и их обсуждение. В статье рассмотрено причины появления сезонного аллергического ринита у беременных женщин, указано особенности его течения. Также показано влияние аллергического ринита на беременность и плод, возможные осложнения и последствия данного заболевания. Приводятся особенности лечения аллергического ринита во время беременности, рассматриваются вопросы, связанные с диагностикой и выбором лекарственного средства с учетом степени потенциальной опасности препаратов для беременной и будущего ребенка. Проанализировав данные литературных источников, авторами статьи было обнаружено, что сезонным аллергическим ринитом страдает около трети женщин репродуктивного возраста, что подчеркивает актуальность и научную значимость данной темы. При беременности симптоматика заболевания несколько изменяется, что усложняет его диагностику. В статье рассматривается вопрос по поводу терапии сезонного аллергического ринита у беременных, особенностью которой есть то, что во время назначения медикаментозной терапии беременным нужно руководствоваться классификацией категорий риска назначенных препаратов (классификация FDA).

Выводы. Беременные, которые страдают аллергическим ринитом, нуждаются в динамическом наблюдении, адекватном лечении, контроле и оценке эсрективности назначенной терапии. Рекомендуется также проведение консилиума в составе аллерголога-иммунолога, акушера-гинеколога, а при необходимости и других специалистов, для определения тактики лечения и профилактики обострений аллергических заболеваний у женщин во время беременности. Незначительное количество работ и изданий по данной теме свидетельствует о том, что исследованием особенностей течения, диагностики, лечения и профилактики аллергических заболеваний во время беременности почти не занимаются ни акушеры-гинекологи, ни аллергологи. Поскольку ряд серьезных осложнений данного заболевания может привести к негативному влиянию на организм как матери, так и ребенка, поэтому вопрос разработки способов профилактики, а также безопасной и эфрфективной терапии является важным и может значительно улучшить качество жизни. Поэтому для сохранения здоровья будущей матери и рождения здорового ребенка необходимы знания о течении аллергического ринита у женщин и при- 
чинах его возникновения. Ведь это даст возможность правильно проводить подготовку, обследование и лечение больных на всех строках беременности.

Ключевые слова: аллергические заболевания; аллергический ринит; беременность; осложнения.

\section{PECULIARITIES AND TREATMENT OF ALLERGIC RHINITIS DURING PREGNANCY}

The aim of the study - review of clinical, peculiarities, therapy and prevention of seasonal allergic rhinitis in pregnant women

Materials and Methods. Literature information of national and world authors in medical library of Thanscarpathian regional medical informational and analytical center and analyzed sources of the Internet.

Results and Discussion. The article considers the reasons of allergic rhinitis during pregnancy, observes its peculiarities. Also, the article shows influence of allergic rhinitis on pregnancy and on fetus, possible complications and consequences of the disease. The insight into treatment characteristics, diagnostics and choice of medical treatment according to the level of potential danger to a pregnant woman and her future child is provided. Analyzed dates of literature sources authors found that nearly third of women during reproductive age suffer seasonal allergic rhinitis, that's why the article is topically and has scientific role. During pregnancy the symptoms of the disease get changes that complicate the diagnostics. The article considers the questions about therapy of seasonal allergic rhinitis in pregnant women, the main in it is that during prescribing of drug's therapy you should guided by classification of categories of risk of the drugs (FDA - Food and Drugs Administration).

Conclusions. Pregnant women with seasonal allergic rhinitis need dynamic monitoring, correct treatment, control and evaluation of effects of the prescribed therapy. Authors also give advice about conduct consultation that consist allergist-immunologist, obstetrician, gynecologist and other medical specialists for determining treatment strategy and prevention of complications of the allergic diseases in women during pregnancy. A small number of experiments and publications about the topic shows that as obstetricians and gynecologists, as allergists don't carry out of learning peculiarities, diagnostics, treatment and prevention allergic diseases during pregnancy. As serious complications of the disease can have negative influence as on mother's organism, as on child, that's why development of the methods of prevention and effective therapy is very important. And it can change quality of life. That's why, if we want to keep future mother and her child healthy, we should learn more about peculiarities of allergic rhinitis in pregnant and its reasons. It gives opportunities for correct preparation, observation and treatment about patients during pregnancy.

Key words: allergic diseases; allergic rhinitis; pregnancy; complications.

ВСтУП. Вагітність - це фрізіологічний процес, який супроводжується глибокими зрушеннями різних функцій жіночого організму, спрямованими на забезпечення потреб плода, який розвивається, та резервів, що дозволяють йому безперервно рости і розвиватися, а також на компенсацію тих фрізіологічних змін організму матері, які при цьому відбуваються. На перебіг вагітності мають значний вплив різні фрактори: вік, маса, наявність супутніх захворювань, характер харчування майбутньої матері, наявність шкідливих звичок, достатнє вживання вітамінів та мікроелементів, стан навколишнього середовища тощо.

Не менш важливу роль відіграє наявність алергічних захворювань у вагітних. Алергічні захворювання $€$ актуальною медико-соціальною проблемою не тільки в Україні, а й у всьому світі, що обумовлено широкою розповсюдженістю, необхідністю проведення адекватної терапії та постійного моніторингу стану пацієнтів з метою просрілактики загострення.

Як і в загальному числі серед населення, так і серед числа вагітних спостерігається значна поширеність і щорічне зростання захворюваності на алергічні захворювання. За останніми даними, частота алергічних захворювань серед них коливається від 5 до 20 \%, а в промислових районах і великих містах цей показник ще вищий $[9,17]$.

При зверненні вагітної до алерголога-імунолога лікар, перш за все, має дати оцінку впливу не лише алергічних захворювань на перебіг вагітності, розвиток плода, організм матері в цілому, а й впливу вагітності на перебіг алергічних захворювань $[11,12]$. Як правило, алергічн захворювання не впливають на перебіг вагітності, а вагітність не сприяє активізації алергічних процесів, більше того, у багатьох пацієнток на тлі гестації настає ремісія алергічних захворювань. Абсолютно доведено, що наявність алергічних захворювань не $є$ протипоказанням до виношування плода та народження дитини [6]. Спостерігаючи вагітну з обтяженим алергічним анамнезом, необхідно враховувати анатомо-фрізіологічні особливості функціонування різних органів і систем у різні терміни гестації з метою призначення адекватної терапії та профрілактики загострень алергічних захворювань.

Одним із найбільш поширених алергічних захворювань $€$ сезонний алергічний риніт. У жінок репродуктивного віку він зустрічається досить часто. Неконтрольований перебіг алергічного риніту під час вагітності може не тільки погіршувати якість життя і ускладнювати перебіг супутніх захворювань, але і приводить до гіпоксії матері і плода.

Алергічний риніт негативно впливає на соціальну активність пацієнтів, різко знижуючи здатність до нормальної життєдіяльності, робочу продуктивність та соціальну активність. Внаслідок цього алергічний риніт можна вважати однією із актуальних і важливих проблем сучасної медицини.

МЕТА ДОСЛІДЖЕННЯ - розгляД особливостей клінічної картини, перебігу, терапії та профрілактики сезонного алергічного риніту протягом вагітності.

МАТЕРІАЛИ ТА МЕТОДИ. БУЛо проведено огляД наукової літератури вітчизняних та зарубіжних авторів і видань у медичній бібліотеці Закарпатського обласного медичного інсрормаційно-аналітичного центру, оглянуто та проаналізовано джерела Інтернету.

РЕЗУЛЬТАТИ ДОСЛІДЖЕННЯ ТА ЇХ ОБГОВОРЕННЯ. Як відомо, разом із нюховою, найважливішою фрункцією носової порожнини є дихальна фрункція. Вагітні особливо чутливі до порушення газообміну і до гіпоксії, у зв'язку 3 чим контроль за симптомами риніту має дуже важливе практичне значення. Такі симптоми, як утруднення носового дихання, ринорея, чхання, свербіж, сльозовиділення негативно впливають на якість життя пацієнтів, у тому 
числі і вагітних жінок, у яких це може призводити до гіпоксії матері та плода, порушення сну, погіршення перебігу супутніх захворювань: бронхіальної астми, хронічних захворювань ЛОР-органів [6, 12].

Поширеність алергічного риніту серед населення достатньо висока і складає 10-30 \%. Приблизно 20-30 \% жінок репродуктивного віку страждають даним захворюванням, а серед їх числа у 10-30 \% випадків спостерігається посилення симптомів алергічного риніту при вагітності $[4,9,17]$. Тому дане алергічне захворювання можна вважати одним із найпоширеніших захворювань, що може ускладнювати перебіг вагітності. При веденн пацієнток з алергічним ринітом у період вагітності повинні вирішуватися як питання вибору лікувальної тактики при раніше верифрікованому діагнозі, так і питання діагностики з наступним алгоритмом спостереження при вперше виявленому захворюванні.

Алергічний риніт - це хронічне алергічне захворювання, в основі якого лежить IgЕ-залежне алергічне запалення, що розвивається в результаті потрапляння алергенів на слизову оболонку носа $[12,13]$. Досить часто алергічний риніт поєднується з бронхіальною астмою і може бути раннім маркером розвитку алергічного процесу в дихальних шляхах.

Фізіологічні процеси в організмі вагітних пов'язані зі зміною гормонального статусу, можуть впливати на активність певних медіаторів, які беруть участь у розвитку запальних та алергічних реакцій. Відомо, що в першому триместрі вагітності плацента має здатність виробляти велику кількість діаміноксидази (гістамінази), в результаті чого в цей період знижується вміст сироваткового гістаміну, що, у свою чергу, може сприяти менш вираженим проявам алергічного риніту у першому триместрі вагітності [7].

Алергічний риніт у вагітних також може поєднуватися 3 неназальними проявами алергії: алергічним кон'юнктивітом, бронхіальною астмою та іншими. При цьому доведено, що алергічний риніт може негативно впливати на перебіг супутніх захворювань, у першу чергу - бронхіальної астми. На даний час $є$ дані, що у $55 \%$ жінок, у яких відмічалося погіршення перебігу бронхіальної астми під час вагітності, одночасно посилювалися і симптоми риніту $[13,16]$.

Потрібно зазначити, що у період вагітності нерідко спостерігається, так званий, гормональний риніт вагітних, пов'язаний із впливом прогестерону $[10,14]$. За даними джерел літератури, від риніту вагітних страждають від 50 до 70 \% вагітних, тому його потрібно диференціювати 3 алергічним ринітом та іншими формами риніту [11, 14].

Риніт вагітних може розвиватися 3 6-го тижня вагітності або пізніше без будь-яких проявів наявності інфекції чи алергії верхніх дихальних шляхів і повністю проходить протягом 2-х тижнів після пологів [8, 16]. Діагностичними критеріями риніту вагітних $є$ скарги хворої, дані анамнезу (скарги з'явилися під час вагітності), результати об'єктивного лОР-огляду. Допоміжними методами можуть бути акустична ринометрія, ендоскопія носової порожнини.

Риніт вагітних накладає відбиток на перебіг алергічного риніту, поглиблюючи його симптоми, і нерідко утрудняє його первинну діагностику при настанні вагітності. $€$ вивчені дані про те, що $\beta$-естрадіол і прогестерон суттєво збільшують експресію гістамінових рецепторів у клітинах епітелію порожнини носа [7]. Результатом цього може стати різка маніфестація назальної гіперреактивності, яка призводить до швидкого розвитку тахіфрілаксії, навіть при короткочасному використанні судинозвужувальних крапель, і посилення симптомів уже наявного алергічного риніту.

При алергічному риніті, на відміну від риніту вагітних, основними причинами виникнення слід вважати різні алергени: пилок рослин, побутові, епідермальні, харчові алергенні чинники [6]. Основні причинно-значущі алергени, що можуть спровокувати розвиток алергічного риніту, бажано виявити до вагітності з метою підбору адекватної терапії та профрілактики загострень у періоди гестації та лактації.

Найбільш типові симптоми алергічного риніту (набряк слизової носа, свербіж, ринорея і чхання) вагітні переносять більш важко. Закладеність носа призводить до утрудненого носового та ротового дихання, що, у свою чергу, обумовлює сухість слизової та дряпання у горлі. Назальна обструкція може стати причиною головного болю, втоми вдень і порушення сну вночі. Все це сприяє зниженню якості життя. При сенсибілізації до побутових алергенів набряклість слизової оболонки носа і пароксизми чхання найсильше проявляються вночі і вранці. Часто можна спостерігати, що закладеність носа більш виражена з того боку, на якому спить пацієнтка. До того ж, внаслідок закладеності носа та утрудненого дихання, виникає хропіння, що, у свою чергу, призводить до підвищення артеріального тиску і розвитку прееклампсії, а також може зумовлювати порушення розвитку плода. При сезонному алергічному риніті у вагітної всі прояви виникають у тому ж періоді року, що і до настання вагітності.

У зв'язку з актуальністю проблеми важливо правильно підходити до питань діагностики і лікування алергічного риніту у вагітних. При верифікації діагнозу «алергічний риніт» у період вагітності можуть бути використані не всі діагностичні тести. Зокрема, під час вагітності протипоказано проведення тестів специфрічної алергодіагностики in vivo: шкірних і провокаційних проб, а також неспецисрічних провокаційних проб, оскільки це може призвести до загострення захворювання і негативно відобразитися на стані вагітної та плода.

3 метою постановки діагнозу або моніторингу стану пацієнтки використовують дані анамнезу, фрізикального та лабораторного обстежень. Основне значення у діагностиці алергічного риніту має алергологічний анамнез, який відіграє у вагітних особливо важливу роль. При цьому звертають увагу на сезонність типових симптомів для риніту або їх появу при контакті з певними алергенами. При опитуванні необхідно отримати інформацію про спадковість, умови життя пацієнтки, про особливості її роботи. Для отримання об'єктивної інформації фрізикальні методи обстеження можуть бути доповнені цитологічними дослідженнями мазків зі слизової і змивами із порожнини носа, при яких частіше за все виявляють еозинофрілію. У випадках верифікації діагнозу алергічного риніту, який дебютує на фоно вагітності, для виявлення причинно-значимих алергенів використовують лабораторні тести специфічної алергологічної діагностики - імуноферментний аналіз (ІФА), метод хемілюмінесценції та інші. Також діагностика алергічного риніту включає визначення специфічних IgE 
в тестах in vitro, таких, як радіоалергосорбентний тест чи метод ImmunoCAP [2, 9].

Лікування алергічного риніту у вагітних має певні особливості, що пов'язані з певними проблемами:

- недостатністю даних щодо ступеня безпечності більшості препаратів під час вагітності;

- категоричною відмовою більшості жінок приймати будь-які ліки під час вагітності;

- відсутністю підтверджених клінічних рекомендацій щодо медикаментозної терапії алергічного риніту під час вагітності.

Традиційні сучасні принципи лікування алергічного риніту включають:

- навчання хворих;

- елімінаційну терапію;

- орармакотерапію;

- специфрічну імунотерапію алергенами (ACIT).

Елімінаційні заходи полягають В усуненні причинного алергену і тригерів або зменшенні контакту 3 ними і $€$ першим і необхідним кроком у лікуванні хворих на алергічний риніт. При лікуванні вагітних рекомендується комплекс елімінаційних заходів, що сприяють зменшенню вираженості клінічних проявів і знижують потребу в медикаментозному лікуванні.

Основним джерелом алергенів домашнього пилу $є$ пилові кліщі. При алергії до домашнього пилу насамперед проводяться заходи, спрямовані на зменшення концентрації алергенів пилових кліщів у житлових приміщеннях. Необхідно добре провітрювати приміщення, сухе прибирання замінити вологим. Водночас слід підтримувати низьку вологість у приміщенні. Подушки і ковдри повинні бути виготовлені зі спеціальних синтетичних матеріалів, періодично їх слід прати. Доцільно використовувати очищувачі повітря, а також хімічні засоби (акарициди), що знищують кліщів. У разі цілорічного алергічного риніту слід відмовитися від застосування сухого корму для риб при наявності в житловому або робочому приміщенні акваріума. Не слід допускати появи тарганів і цвілевих грибів у приміщенні $[4,6]$.

Єдиним ефективним заходом щодо елімінації алергенів шерсті тварин і пера птахів є вилучення тварин 3 дому і ретельне прибирання приміщення. При цьому очікуваний есрект елімінаційних заходів може проявитися повною мірою лише через кілька тижнів або місяців після роз'єднання з причинними тваринами при продовженні проживання пацієнта в тому ж самому приміщенні. Слід мати на увазі, що такі заходи, як миття тварини та виключення його перебування в спальні, бувають недостатніми для того, щоб повністю елімінувати епідермальні алергени.

При наявності пилкової сенсибілізації елімінаційні заходи повинні бути спрямовані на обмеження контакту з пилком: обмеження прогулянок в суху спекотну вітряну погоду і поїздок за місто. Для попередження потрапляння пилку на слизові верхніх дихальних шляхів і очей рекомендуються часте умивання, носіння сонцезахисних окулярів, зміна одягу при поверненні додому 3 вулиці, прийняття душу після перебування на вулиці, особливо перед сном і т. п. Поряд з цим, у період цвітіння причинно-значущих рослин слід попереджати потрапляння пилку рослин у житлові приміщення, в тому числі з повітрям через відкриті вікна і з пилом на вуличному взутті. Для зниження концентрації пилку в приміщенні в сезон загострення рекомендується використовувати очищувачі повітря.

Особливе місце в профрілактиці і лікуванні алергічного риніту у вагітних займає іригаційно-елімінаційна терапія, коли використовуються ізотонічні сольові розчини, створені на основі океанічної або морської води. Інтраназальне застосування зазначених засобів приводить до зволоження слизової, поліпшення її бар'єрної фрункції, зумовлює зменшення алергенного навантаження, що сприяє зниженню вираженості алергічного запалення.

В останні роки заслужений інтерес викликають бар'єрні методи фрармакотерапії алергічного риніту, особливо актуальні в період вагітності. Так, за даними джерел літератури, природний бар'єр для потрапляння алергенів і полютантів на слизову носа може бути створений при використанні препарату «Назаваль» (спрей назальний дозований), що являє собою мікродисперсний порошок целюлози $[3,4]$. Целюлоза $є$ інертною речовиною, яка при інстиляції із спрею-дозатора на слизову носових ходів зв'язується зі слизом і у вологому середовищі утворює міцну гелеподібну плівку, формуючи механічний бар'єр для проникнення аероалергенів і полютантів [15]. Важливою перевагою назавалю $є$ його безпека і можливість використання у дітей і літніх осіб, жінок у період вагітності та годування груддю. Назаваль не містить діючих фрармакологічних речовин і не має системної дії; $\epsilon$ захисним медичним засобом, придатним для тривалого використання. Ефективність препарату «Назаваль» при алергічному риніті, згідно з результатами проведених досліджень, досягала 77 \% [3, 7]; його використання знижувало потребу в застосуванні інших препаратів для контролю симптомів сезонного алергічного риніту. Дія мікроцелюлози при алергічному риніті розвивається швидко: вже на першому тижні як у дорослих, так і у дітей зменшуються симптоми алергічного риніту $[18,20]$.

У тих випадках, коли вищеперераховані заходи неефективні, виникає потреба у застосуванні медикаментозної терапії. При цьому слід пам'ятати, що призначаються тільки ті препарати, які не викликають несприятливого впливу на плід. Всі медикаментозні препарати мають різний ступінь ризику впливу на перебіг вагітності та розвиток плода.

При призначенні медикаментозної терапії вагітним у багатьох країнах орієнтуються на розроблену класисрікацію категорій ризику призначення препаратів. Це класифрікація Управління з контролю за харчовими продуктами і лікарськими препаратами США (FDA - Food and Drugs Administration), розроблена в 1979 р. Дана класифрікація ділить всі лікарські препарати для лікування вагітних на 5 категорій залежно від їх потенційного ризику (табл.) [5].

До лікарських препаратів, які використовуються для лікування алергічного риніту і дозволені до застосування у вагітних, належать:

- препарати кромогліциєвої кислоти - вони є достатньо безпечними (категорія В), але рідко розглядаються в якості препаратів вибору під час вагітності через достатньо низьку їх ефективність;

- антигістамінні препарати місцевої дії - левокабастин, азеластин.

Антигістамінний препарат «Азеластин (Алергодил)» показав високу ефективність при алергічному риніті. Азеластин - похідне срталазинолу. Він є седативним 
Таблиця. Класифікація FDA

\begin{tabular}{|l|l|l||}
\hline Категорія & \multicolumn{1}{|c|}{ Назва } & \multicolumn{1}{|c||}{ Визначення } \\
\hline A & Безпечні & $\begin{array}{l}\text { Тератогенної дії препаратів не було виявлено ні в клініці, ні в експерименті. Може } \\
\text { застосовуватися у будь-які терміни вагітності }\end{array}$ \\
\hline B & Умовно безпечні & $\begin{array}{l}\text { Відсутня тератогенність препаратів в експерименті на тваринах, однак адекватних } \\
\text { клінічних даних немає. Або дослідження на тваринах показали несприятливий } \\
\text { вплив на плід, але в достатній кількості досліджень за участю вагітних жінок не було } \\
\text { продемонстровано ризику для плода ні в першому, ні в наступних триместрах вагітності }\end{array}$ \\
\hline C & $\begin{array}{l}\text { Потенційно } \\
\text { небезпечні } \\
\text { контролю немає. Або ще немає достатньої кількості досліджень ні на тваринах, ні за } \\
\text { участю вагітних жінок }\end{array}$ \\
\hline D & Небезпечні & $\begin{array}{l}\text { Препарати надавали несприятливу дію на плід в експерименті, але потенційна користь } \\
\text { від їх використання перевищує ризик несприятливої дії на плід }\end{array}$ \\
\hline X & Препарати з тератогенністю, доведеною в експерименті та клініці \\
\hline \hline
\end{tabular}

$\mathrm{H}_{1}$-гістаміноблокатором, надає антигістамінну, протиалергічну дію, знижує проникність капілярів та ексудацію, стабілізує мембрану опасистих клітин і перешкоджає вивільненню 3 них біологічно активних речовин, що викликають бронхоспазм і сприяють розвитку ранньої та пізньої стадій алергічних реакцій і запалення. Азалестин за ефективністю не поступається препаратам системної дії, наприклад лоратадину [6];

- топічні (назальні) ГКС - безпечність даної групи препаратів було доведено в багатьох клінічних дослідженнях. Прийом фрлутиказону пропіонату в період гестації не справляв побічного впливу на організм матері і перебіг вагітності. Найбільш вивченим препаратом серед ГКС $€$ будесонід, який вважається препаратом першого вибору 3 числа назальних ГКС у вагітних $[4,6]$. Високий рівень безпеки інтраназального будесоніду і його низька системна біоактивність підтверджені в ряді досліджень. Також встановлено, що суспензія будесоніду не передається через грудне молоко [5, 7]. Як і всі препарати при вагітності, інтраназальні ГКС повинні застосовуватися в мінімально ефективній дозі $[6,13,19]$.

ВИсновкИ. Алергічний риніт є частим захворюванням і актуальною проблемою в багатьох країнах світу. Особливо правильно потрібно підходити до вирішення даної проблеми в акушерстві. Під час вагітності в організмі жінки виникає цілий ряд адаптаційних змін, направлених на забезпечення адекватного перебігу вагітності, росту і розвитку плода. Значна перебудова життєдіяльності організму пов'язана зі змінами в системі крові, гемостазу та ендокринній системі. Все це може призвести до погіршення перебігу супутніх захворювань, в тому числі й алергічного риніту.

Вагітні з алергічним ринітом потребують динамічного спостереження, адекватного лікування, контролю і оцінки ефективності призначеної терапії. Передбачається планове проведення консиліуму у складі алерголога-імунолога, акушера, а при необхідності й інших спеціалістів, 3 метою визначення тактики лікування та профілактики загострень алергічних захворювань під час вагітності.

Саме тому для збереження здоров'я майбутньої матері і народження здорової дитини такими необхідними є знання про перебіг алергічного риніту у вагітних і причини його виникнення. Адже це дасть можливість правильно проводити підготовку, спостереження та лікування хворих на всіх строках вагітності.

ПЕРСПЕКТИВИ ПОДАЛЬШИХ ДОСЛІДЖЕНЬ. На жаль, дослідженнями, направленими на розробку тактики ведення вагітних, хворих на риніт, не займаються ані акушери-гінекологи, ані алергологи чи отоларингологи, про що свідчить наявність незначної кількості праць, присвячених цій темі. Це є дуже прикрим орактом, оскільки стійке порушення носового дихання може призвести до розвитку тяжких ускладнень не тільки у матері, а й у плода. Ось чому таким важливим $є$ питання розробки способів профрілактики і безпечної та ефрективної терапії, що може значно покращити якість життя.

\section{СПИСОК ЛІТЕРАТУРИ}

1. Курбачева О. М. Аллергический ринит и беременность: возможности современной терапии / О. М. Курбачева, С. М. Швец // Эффрективная фрармакотерапия. - 2013. № 18. - C. 74-80.

2. Аллергология и иммунология : национальное руководство / под ред. Р. М. Хаитова, Н. И. Ильиной. - М. : ГЭОТАР-Медиа, 2009. - 656 с.

3. Возможности использования нового назального спрея Назаваль в лечении и просилактике аллергического ринита / Т. В. Захаржевская, И. В. Сидоренко, В. К. Трескунов [и др.] // Российский аллергологический журнал. - 2009. № 4. - С. 82-86.

4. Анализ подходов к лечению сезонного аллергического ринита у беременных / А. А. Камелева, Н. А. Чухарева,
Е. О. Халтурина [и др.] // Научно-практический журнал «Акушерство и гинекология». - 2016. - № 7. - С. 46-52.

5. Кречиков В. А. Риск применения лекарственных препаратов при беременности: фокус на будесониде / В. А. Кречиков, С. Н. Козлов // Атмосорера. Пульмонология и аллергология. - 2008. - № 3. - С. 22-26.

6. Лусс Л. В. Алергія та вагітність / Л. В. Лусс // Педіатрія, акушерство та гінекологія. - 2012. - Т. 75, № 2. C. 101-108.

7. Лопатин А. С. Диагностика и лечение ринита и риносинусита у беременных / А. С. Лопатин // Российский аллергологический журнал. - 2006. - № 1. - С. 6-12.

8. Пухлик С. М. Ринит у беременных / С. М. Пухлик // Ринология. - 2003. - № 4. - С. 18-23. 
9. Васильева А. А. Тактика ведения больных аллергическим ринитом в период беременности / А. А. Васильева, Р. Ф. Хакимова // Вестник современной клинической медицины. - 2015. - Т. 8, вып. 2. - С. 82-88.

10. Черных Н. М. Ринит беременных / Н. М. Черных // Российская ринология. - 2008. - № 4. - С. 31-33.

11. Шехман М. М. Острые респираторные заболевания у беременных / М. М. Шехман, Л. А. Положенкова // Гинекология: журнал для практических врачей. -2005. -Т. 7, № 2. - С. 96-99.

12. Юрочко Ф. Алергічний риніт. Відповіді не тільки для алергологів / Ф. Юрочко // Ринологія. - 2012. - № 2. - С. 59-64.

13. Allergic Rhinitis and its Impact on Asthma (ARIA) 2008 update (in collaboration with the World Health Organization, GA(2)LEN and AllerGen) / J. Bousquet, N. Khaltaev, A. Cruz [et al.] // Allergy. - 2008. - Vol. 63, Suppl. 86. - P. 8-160.

14. Ellegard E. K. Pregnancy rhinitis / E. K. Ellegard // Immunol. Allergy Clin. North Am. - 2006. - Vol. 26 (1). - P. 119-135.

15. Emberlin J. C. Double blind placebo controlled cross over trial of inert cellulose powder, by nasal provocation with grass pollen to assess efficacy of the product in controlling symptoms of hay ferer in adults / J. C. Emberlin, R. A. Lewis // Curr. Med. Res. Opin. - 2006. - Vol. 22, № 2. - P.275285.

16. Rhinitis in pregnancy / F. Gani, A. Braida, C. Lombardi [et al.] // Eur. Ann. Allergy Clin. Immunol. - 2003. - Vol. 35 (8). - P. 306-313.

17. Incaudo G. A. Diagnosis and treatment of allergic rhinitis and sinusitis during pregnancy and lactation / G. A. Incaudo // Clin. Rev. Allergy Immunol. - 2004. - Vol. 27(2). - P.159-178.

18. Josling $P$. Use of cellulose powder for the treatment of seasonal allergic rhinitis / P. Josling, S. Steadman // Adv. Ther. - 2003. - Vol. 20, № 4. - P. 213-219.

19. Keles N. Treatment of allergic rhinitis during pregnancy / N. Keles // Am. J. Rhinol. - 2004. - Vol. 18(1). - P. 23-28.

20. Treating common problems of the nose and throat in pregnancy: what is safe? / P. V. Vlastarakos, L. Manolopoulos, E. Ferekidis [et al.] // Eur. Arch. Otorhinolaryngol. - 2008. Vol. 265 (5). - P. 499-508.

\section{REFERENCES}

1. Kurbacheva, O.M., \& Shvets, S.M. (2013). Allergicheskii rinit i beremennost: vozmozhnosti sovremennoi terapii [Allergic rhinitis and pregnancy: the possibilities of modern therapy]. Effectivnaia farmakoterapiia - Effective pharmacotherapy, 18, 74-80 [in Russian].

2. Khaitov, R.M., \& Illina, N.I. (2009). Alergologiia i immunologiia [Allergy and immunology ]. Moscow: GEOTAR-Media [in Russian].

3. Zakhapzhevskaia, T.V., Sydorenko, I.V., Treskunov, V.K. (2009). Vozmozhnosti ispolzovaniia novogo nazalnogo spreia Nazaval $v$ lechenii i profilaktiki allergicheskoho rinita [The possibilities of using of the modern nasal spray Nazaval in the treatment and prevention of allergic rhinitis]. Rossiiskii allergologicheskii zhurnal - Russian Allergy Journal, 4, 82-86 [in Russian].

4. Kameleva, A.A., Chukhareva, N.A., Khalturina, Ye.O., Yesaian, R.M., Ushkalova, Ye.A., \& Tkacheva, O.N. (2016). Analiz podkhodov $\mathrm{k}$ lecheniiu sezonnogo allergicheskogo rinita $u$ beremmennykh [The analysis of approaches to the treatment of season allergic rhinitis in pregnant]. Akusherstvo i ginekologiia - Obstetrics and Gynecology, 7, 46-52 [in Russian].

5. Krechikov, V.A., \& Kozlov, S.N. (2008). Risk primineniia lekarstvennykh preparatov pri beremennosti: focus na budesonide [The risk of using medication during pregnancy: focus on budesonide]. Atmosfera. Pulmonologiia i allergologiiaAtmosphere. Pulmonology and Allergology, 3, 22-26 [in Russian]

6. Luss, L.V. (2012). Alergiia ta vahitnist [Allergy and pregnancy]. Pediatriia, akusherstvo ta ginekologiia - Pediatric, Obstetrics and Gynecology, 2, 101-108 [in Ukrainian].

7. Lopatin, A.S. (2006). Diagnostika i lecheniie rinita i rynosinusita $u$ beremennykh [Diagnostics and treatment of rhinitis and rynosynusit in pregnant]. Rossiiskii allergologicheskii zhurnal - Russian Allergy Jornal, 1, 6-12 [in Russian].

8. Pukhlik, S.M. (2003). Rinit u beremennykh [Rhinitis in pregnant]. Rinologiia - Rhinology, 4, 18-23 [in Russian].

9. Vasilieva, A.A., \& Khakimova R.F. (2015). Taktika vedeniia bolnykh allergicheskim rinitom $v$ period beremennosti [Treatment of allergic rhinitis in women during pregnancy]. Vesnik sovremennoi klinicheskoi meditsiny - Messenger of Modern Medicine, 8(2), 82-88 [in Russian].

10. Chernykh, N.M. (2008). Rinit beremennykh [Rhinitis in pregnant]. Rossiiskaia rinologiia - Russian Rinology, 4, 31-33 [in Russian].

11. Shekhman, M.M., \& Polozhenkova, L.A. (2005). Ostryie respiratornyie zabolevanie u beremennykh [Acute respiratory diseases in pregnant]. Ginekologiia: zhurnal dlia practicheskikh vrachei - Gynecology: Journal for Practical Doctors, 2, 96-99 [in Russian]

12. Yurochko, F.B. (2012). Alerhichnyi rynit. Vidpovidi ne tilky dlia alerholohiv [Allergic rhinitis. Answers not only for allergists]. Rynologiia - Rhinology, 2, 59-64 [in Ukrainian].

13. Bousquet J., Khaltaev N., Cruz A. (2008). Allergic Rhinitis and its Impact on Asthma (ARIA) 2008 update (in collaboration with the World Health Organization, GA(2)LEN and AllerGen). Allergy, 63, (86), 8-160.

14. Ellegard, E.K. (2006). Pregnancy rhinitis. Immunol. Allergy Clin. North Am., 26 (1) 119-135.

15. Emberlin, J.C. (2006). Double blind placebo controlled cross over trial of inert cellulose powder, by nasal provocation with grass pollen to assess efficacy of the product in controlling symptoms of hay ferer in adults. Curr. Med. Res. Opin. 22, (2), 275-285.

16. Gani, F., Braida, A., Lombardi, C., Del Giudice, A., Senna, G.E., Passalacqua, G. Rhinitis in pregnancy. Eur. Ann. Allergy Clin. Immunol., 35 (8), 306-313.

17. Incaudo, G.A. (2004). Diagnosis and treatment of allergic rhinitis and sinusitis during pregnancy and lactation. Clin. Rev. Allergy Immunol., 27(2), 159-178.

18. Josling, P., Steadman, S. (2003). Use of cellulose powder for the treatment of seasonal allergic rhinitis. Adv. Ther., 20 (4), 213-219.

19. Keles, N. (2004). Treatment of allergic rhinitis during pregnancy. Am. J. Rhinol., 18 (1), 23-28.

20. Vlastarakos, P.V., Manolopoulos, L., Ferekidis, E., Antsaklis, A., Nikolopoulos, T.P. (2008). Treating common problems of the nose and throat in pregnancy: what is safe? Eur. Arch. Otorhinolaryngol. 265 (5), 499-508. 